\title{
Research on the Credit Risk Influencing factors of Farmer Loan for Rural Commercial Bank Based on Probit Model
}

\author{
Ya-Qiong Pan ${ }^{1, a,}$, Ze-Qun Song ${ }^{2, b}$ \\ ${ }^{1,2}$ School of Management, Wuhan University of Science and Technology, Wuhan 430081, China \\ apanyaqiong2002@sina.com, ${ }^{\mathrm{b}} 1085286109 @ q q . c o m$ \\ ${ }^{*}$ Corresponding author
}

Keywords: Rural commercial bank, Farmer loan, Credit risk, Influence factors, Probit model.

\begin{abstract}
This paper takes farmer loan for Rural Commercial Bank as an object of study, discusses the credit risk and its influence factors. Based on the survey data from Hubei Rural Commercial Bank, Probit model is applied to analyze these factors. The findings are showed as follows: There is a significant and negative relationship between the credit risk of farmer loan and the number of family labor and total household assets, while the total hou sehold debt and loan rates affect it positively. In addition, whether the households have children in university, whether the loan secured and the loan purposes also have significant effect on the credit risk. Therefore, Rural Commercial Bank should examine the basic information of farmers carefully; implement preferential interest rate policy; encourage productive and secured loan to prevent the occurrence of credit risk.
\end{abstract}

\section{Introduction}

In the rural credit market of our country, Rural Commercial Bank has become one of the main providers of farmer loan with the fact that rural credit cooperatives and rural cooperative banks fully restructure to this market, and State-owned banks withdraw from rural areas gradually. However, the rate of non-performing loans to farmers remain high in recent years that makes the Rural Commercial Bank produce a fear emotion to farmer loan. If the credit risk of farmer loan cannot be evaluated and controlled effectively, that certainly will affect the overall credit quality of agricultural businesses, and thus hinder the development of rural economy.

Currently, many experts and scholars put the focus on large-scale state-owned commercial banks, and ignore this special group--Rural Commercial Bank; the research mainly for listed companies and SME, lake of research on farmer loan which has dual characteristics of commercial and policy. In view of this, this paper takes the farmer loan of Rural Commercial Bank as an object of study, discusses the credit risk and its influence factors, establishes a evaluation index system of credit risk of farmer loan, and empirically studies this problem by Probit probability model based on the survey data from Hubei Rural Commercial Bank.

\section{Literature review}

\section{Factors of credit risk of farmer loan}

In recent years, domestic and foreign scholars study on various factors, most of which are based on the basic characteristics of farmers and their families, wealth ownership, loan characteristics, environmental characteristics etc. to establish the risk assessment system of farmer loan. Related researches as shown in Table 1.

In addition, Godquin (2004) found that the repayment behavior of Microfinance farmers was influenced by the group guarantees and dynamic incentives [1]. Li Yan et al (2014) [2] considered that the factors of lending practices of farmers in different regions are quite different, and efficient policies should be taken to the farmers in different development region and stages. 
Tab. 1 Major Factors of domestic and foreign on credit risk of farmer loan

\begin{tabular}{|c|c|}
\hline Related literature & Factors of credit risk of farmer loan \\
\hline $\begin{array}{l}\text { Liu Baolei, Zhang Yuanyuan(2009) } \\
\text { Zhang Yunyan, Wang Fang, Luo Jianzhao (2013) }\end{array}$ & $\begin{array}{l}\text { Farmers own characteristics: } \\
\text { Age, Sex, Marital status, Education }\end{array}$ \\
\hline $\begin{array}{l}\text { Rubana Mahjabeen(2008) } \\
\text { Kong Rong, Chen Chuanmei, Yi Minghui(2010) } \\
\text { Lai Yongwen, Liu Weiping(2012) }\end{array}$ & $\begin{array}{l}\text { Farmer household characteristics: } \\
\text { The total number of households } \\
\text { Labor force } \\
\text { The number of children in university }\end{array}$ \\
\hline $\begin{array}{l}\text { S.Jha\&K.S.Bawa(2007) } \\
\text { Xie Bing(2009) } \\
\text { Liu Yingzhou, Zhou Guanglu, Luo Jianzhao(2010) }\end{array}$ & $\begin{array}{l}\text { Household wealth ownership: } \\
\text { Household income and expenditure } \\
\text { Total household assets } \\
\text { Total household debt }\end{array}$ \\
\hline $\begin{array}{l}\text { Jose A.G. Baptista(2006) } \\
\text { Huang Haiyuan(2010) } \\
\text { Li Liyan, Li Xiaohong(2013) }\end{array}$ & $\begin{array}{l}\text { Loan characteristics: } \\
\text { Line of credit, Loan cycle } \\
\text { Interest rate and Loan period } \\
\text { Loan Purpose } \\
\text { Whether secured or mortgage }\end{array}$ \\
\hline $\begin{array}{l}\text { Li Zhanjiang, Chi Guotai(2013) } \\
\text { Gao Jian, Wang Ninglan(2012) }\end{array}$ & $\begin{array}{l}\text { External environmental characteristics: } \\
\text { Macroeconomic environment } \\
\text { The level of economic development of residence } \\
\text { Government support }\end{array}$ \\
\hline
\end{tabular}

\section{Research Methods of credit risk of farmer loan}

Credit score. Most of foreign scholars adopt this method, a representative of this approach is the Z-score model which was released by Professor Altman in 1968[3]. it took advantage of the important financial ratios to predict the possibility of bankruptcy at that time, but now it is used to study the default possibility of farmer loan. Robert DeYoung (2001) constructed Stacked-Fogit model, and empirically analyzed the impact of various influence factors on the credit score of farmer loan.

Logistic model measurement methods. The dependent variable of this model is a regression analysis for evaluation of secondary scoring or second type. Li Meng (2005) took Logit Model to assess the credit risk of Commercial Bank, and found that Logit model has the very credible ability of identification, prediction and generalization. Zhang Ai-rong \& Song Hongyuan, Li Liyan \& Li Xiaohong [4], Huang Haiyuan et al used Logit model to study the credit risk.

Fuzzy Comprehensive Evaluation Method. Because the selection of evaluation index and criteria and the determination of the weight all have certain fuzziness, so this method has strong applicability on the farmers' loan credit risk assessment. Yang Chang (2013), on the basis of fuzzy comprehensive evaluation, used a mutation model to analyze the farmer credit risk, which avoided the subjectivity and arbitrariness of risk assessment, and improved the accuracy of the evaluation.

In addition to these three main research methods, as well as panel regression, Co integration and VAR model, Projection Pursuit Model et al.

In summary, few scholars study the issue from the perspective of rural commercial banks; research method is more focused on Logistic model and fuzzy comprehensive evaluation method. Therefore, on the basis of previous studies, this paper empirically analyzes the influence factors of credit risk of farmer loan by Probit model from the perspective of Rural Commercial Bank.

\section{Empirical model of credit risk influence factors of farmer loan}

\section{Model selection}

This paper takes Probit Model, proposed by McFadden (D.Mcfadden), which is based on effect or behavioral choice theory to estimate. Specific expression is:

$$
\mathrm{Y}^{*}=\beta_{0}+\beta \mathrm{x}+\mu
$$

And 


$$
\mathrm{Y}=\left\{\begin{array}{l}
1, \text { when } \mathrm{Y}^{*}>0 \text {, farmer loan defaults. } \\
0, \text { when } \mathrm{Y}^{*} \leq 0, \text { farmer loan does not default. }
\end{array}\right.
$$

In Eq. 1 and 2, orders $\mathrm{Y}^{*}$ is an unobservable latent variable; $\mathrm{Y}$ is the actual observed dependent variable, which indicates that whether farmer loan defaults. $\mu$ is assumed independent of $x$, and subjected to the error term of standard normal distribution. Therefore, the binary discrete choice model of the credit risk influence factors of farmer loan can be expressed as:

$$
\begin{aligned}
\operatorname{Prob}(\mathrm{Y}=1 \mid \mathrm{X}=\mathrm{x}) & =\operatorname{Prob}\left(\mathrm{Y}^{*}>0 \mid \mathrm{x}\right)=\operatorname{Prob}\left(\beta_{0}+\beta \mathrm{x}+\mu>0 \mid \mathrm{x}\right)=\operatorname{Prob}\left[\mu>-\left(\beta_{0}+\beta \mathrm{x}\right) \mid \mathrm{x}\right] \\
& =1-\phi\left[-\left(\beta_{0}+\beta \mathrm{x}\right)\right]=\phi\left[\beta_{0}+\beta \mathrm{x}\right] .
\end{aligned}
$$

In Eq. 3, $\phi$ is the standard normal cumulative distribution fuction of $\mu . \mathrm{X}$ is a vector of factors. $\mathrm{x}$ is the actually observe factors, including the basic characteristics of farmers and their family, wealth ownership and loan characteristics in this paper.

\section{Data sources}

Data in this paper selected a random sample of 230 from a branch of Hubei Rural Commercial Bank. And the data is screened according to the need of the study, excluding the 24 key missing samples, and leaving 206 valid samples. In these 206 valid samples, loan defaults are 16, not defaults are 200, and the default rate is $7.8 \%$. Due to the significant difference in total hou sehold assets and debt, annual household income, loan amount and some other variables, this paper referenced the approach of Li Zhengbo in order to avoid errors. Standardized the variables and the result can be calculate by (original value - arithmetic mean)/ standard deviation of the value.

\section{Select variables and Hypotheses}

Factors affecting the credit risk of farmer loan are a lot; this paper referenced the result of Zhang Lina \& Wang Jing, Kong Rong, Niu Xia, Li Yan and Li Liyan \& Li Xiaohong, and then selected 12 factors as

\begin{tabular}{|c|c|c|c|}
\hline \multicolumn{2}{|l|}{ Variables } & Varibles connotation & intended direction \\
\hline \multicolumn{2}{|l|}{$\mathrm{y}$} & Whether defaul: $\mathrm{Yes}=1 ; \mathrm{No}=0$ & \\
\hline \multirow{4}{*}{$\begin{array}{l}\text { the basic characteristics } \\
\text { of farmers and their } \\
\text { family }\end{array}$} & $\mathrm{X}_{1}$ & Age & + \\
\hline & $\mathrm{X}_{2}$ & $\begin{array}{l}\text { Education: Undergraduate and above }=1 ; \text { Junior } \\
\text { college }=2 ; \text { Hight school or technical secondary } \\
\text { school=3; Junior high school=4; Primary school }=5 \text {. }\end{array}$ & + \\
\hline & $\mathrm{X}_{3}$ & Number of family labor & - \\
\hline & $\mathrm{X}_{4}$ & Whether to have children in university: $\mathrm{Yes}=1 ; \mathrm{No}=2$ & \\
\hline \multirow{3}{*}{ wealth ownership } & $\mathrm{X}_{5}$ & Total household assets(million yuan) & - \\
\hline & $\mathrm{X}_{6}$ & Total household debt (million yuan) & + \\
\hline & $\mathrm{X}_{7}$ & Annual household income(million yuan) & - \\
\hline \multirow{5}{*}{ loan characteristics } & $\mathrm{X}_{8}$ & Loan rates $(\%)$ & + \\
\hline & $\mathrm{X}_{9}$ & $\begin{array}{c}\text { Loan term: within six months }=1 \text {; six months to a } \\
\text { year }=2 \text {;one to three years }=3 \text {; three years }=4\end{array}$ & + \\
\hline & $\mathrm{X}_{10}$ & Loan amount(million yuan) & + \\
\hline & $\mathrm{X}_{11}$ & Whether guarantee: $\mathrm{Yes}=1 ; \mathrm{No}=2$ & \\
\hline & $\mathrm{X}_{12}$ & $\begin{array}{l}\text { Loan purposes: Productive loan }=1 \text {; consumption } \\
\qquad \text { loan }=2\end{array}$ & \\
\hline
\end{tabular}
explanatory variables. Specific variables and description are in Table 2.

Tab.2 Definitions of the variables and the intended direction of the credit risk of farmer loan

Combined with the relevant theory and literature, this paper proposed the following hypotheses:

(1) The basic characteristics of farmers and their family. The age and education can reflect the overall quality and stability of the family. Assume that the higher overall quality and the better stability of the family, the less credit risk will generate; the more the number of family labor, the more income to 
households which will lead to smaller credit risk; there are children to university, household spending will increase and credit risk will increase accordingly.

(2) Wealth ownership. According to local realities, total household assets include the real estate, fixed assets and other household consumer durables. This indicator reflects the stock of household assets, assuming that it has an inversely proportional relationship with farmer credit risk. Total household debt include the loans in the bank and private loans, assuming that the more total household debt, the greater credit risk. Household income include wages and salaries, types of farming income, migrant workers and self-employed business income and other income, assuming that the higher the income, the less the likelihood of default.

(3) Loan characteristics. Assume that the smaller the amount of the loan, the shorter the term, the lower the interest rates, the less likely the farmer will default; secured loans to farmers, the possibility of timely repayment will be higher, the less the likelihood of default. Loan purpose is divided into productive loan and consumption loan. Productive loan is easier to create value and has stronger liquidity; therefore this article assumes that it has smaller credit risk.

\section{The empirical results and analysis}

\section{Model estimation results}

This paper uses Eviews6.0 software, excluding the explanatory variable which has too many missing data and significance is not strong, and in turn to cut out the householder age, education level, family income, loan time limit and loan amount, regression analysis was carried out on the simplified index again, results are as follows:

Tab.3 Measurement results of the credit risk influence factors of farmer loan

\begin{tabular}{|c|c|c|c|c|}
\hline Variable & Coefficient & $\begin{array}{l}\text { Standard } \\
\text { deviation }\end{array}$ & Statistics & Prob. \\
\hline $\mathrm{C}$ & -0.372598 & 1.624476 & -0.229365 & 0.8186 \\
\hline $\mathrm{X}_{3}$ & -0.803563 & 0.330318 & -2.432697 & 0.0150 \\
\hline $\mathrm{X}_{4}$ & -1.518293 & 0.462384 & -3.283617 & 0.0010 \\
\hline $\mathrm{X}_{5}$ & -1.096987 & 0.488734 & -2.244549 & 0.0248 \\
\hline $\mathrm{X}_{6}$ & 0.88279 & 0.259896 & 3.396708 & 0.0007 \\
\hline $\mathrm{X}_{8}$ & 0.700054 & 0.278233 & 2.516069 & 0.0119 \\
\hline $\mathrm{X}_{11}$ & 1.081287 & 0.450519 & 2.40009 & 0.0164 \\
\hline $\mathrm{X}_{12}$ & 1.017668 & 0.405333 & 2.510696 & 0.0120 \\
\hline \multicolumn{7}{|c|}{0.541437} & \multicolumn{2}{|c|}{ Mean dependent var } & 0.077670 \\
\hline \multicolumn{2}{|c|}{60.90787} & \multicolumn{2}{|c|}{ Prob(LR statistic) } & 0.000000 \\
\hline
\end{tabular}

From the regression results, $\mathrm{R}^{2}$ is 0.54 , indicating that whole model fitting degree is good; LR statistic is 60.91 , corresponding to the $\mathrm{P}$ value is 0 , show that the model as a whole is significant; all the explanatory variables under the significance level of $5 \%$ by significance test, show that variable significance is very high, and the stability and reliability of the model are good.

Above all, Probit model of the credit risk influence factors of farmer loan as follows:

$$
\begin{aligned}
\mathrm{Pi} & =\phi(\mathrm{yi}) \\
& =\phi\left[\begin{array}{l}
-0.3726-0.8036 \mathrm{X}_{3}-1.5183 \mathrm{X}_{4}-1.097 \mathrm{X}_{5}+0.8828 \mathrm{X}_{6} \\
+0.7001 \mathrm{X}_{8}+1.0813 \mathrm{X}_{11}+1.0177 \mathrm{X}_{12}
\end{array}\right]
\end{aligned}
$$

In Eq. 4, $\mathrm{P}$ for the probability of default; $\phi()$ show that the function is normal distribution; the results can be obtained by finding the normal distribution table. $\mathrm{X}_{3}, \mathrm{X}_{4}, \mathrm{X}_{5}, \mathrm{X}_{6}, \mathrm{X}_{8}, \mathrm{X}_{11}, \mathrm{X}_{12}$ followed by the 
number of family labor, Whether to have children in university, total household assets, total household debt, interest rates, whether guarantees and loan purpose.

\section{Results analysis}

According to the results of the model output, the effect factors of farmer loans credit risk analysis as follows:

Number of family labor. The Regression coefficient is 0.803563 , under $5 \%$ significance level through the inspection; show that this variable has a significant negative effect on the probability of default, which is consistent with the hypothesis. The reason may be: one is along with the increase of the number of labor, the capacity of creating wealth will gradually strengthen, so families have surplus money to repay the loan; the other is that local rural Hubei considers the planting citrus income as the mainstay of families' income. Therefore the more the labor, the better the effect of planting and harvesting will be, and this will create more income to reduce the likelihood of default.

Whether to have children in university. The regression results show that the farm households who have children in university have a greater default probability than childless. The reason may be: first, if there are children to go to university, rural households farmers will take most of the family income to pay tuition fees and living expenses, so the money used to repay the loan will be reduced; second, there are children in university will reduce the labor force, and college students rarely create wealth for the household during the period of school, this will also bring difficulties to farmers to repay the loan.

Total household assets. The regression coefficient is 1.096987, under 5\% significance level through the inspection; show that this variable has a significant negative effect on the probability of default, which is consistent with the hypothesis. The more total household assets, the larger the ownership of their wealth and the smaller the probability of default. In addition, the likelihood of default intentionally of this farmer is small.

Total household debt. The regression coefficient is 0.88279 , under $1 \%$ significance level through the test of significance; indicate that this variable has significant positive influence on probability of default. The reason may be that the farmer will probably use the loan of rural commercial bank capacity to pay off the folk loan; therefore, the bank loan cannot create surplus value in a short time, which will affect the reimbursement possibility.

Loan rate. The regression coefficient is 0.700054 , under $5 \%$ significance level through the inspection; show that loan rate has obvious positive influence on the probability of default, which is consistent with the hypothesis. Because the higher the loan rate, the higher the interest will be, and the annual interest is likely to bring more burden to the farmer, which cause farmers contracted to repay the loan.

Whether the guarantee. The results showed that the farmers of loans secured have lower probability of default than farmers without guarantee. In the sample, the third person's property or farmers own property is used to guarantee. In the countryside, people pay more attention on the credibility and reputation of neighborhood, so in order not to damage the prestige, the enthusiasm of farmer's reimbursement will enhance and the likelihood of default intentionally will be also reduced.

Loan purposes. The results show that the productive loan has smaller default probability compared with consumption loan. The reason may be that the productive loan can create profit for farmers in a short term, and increase the capability of repayment of farmers. However, consumption loan do not have this effect; the majority of consumption loan are used for building and decoration housing, student loan and so on, the loan will not create value, so consumption loan have greater default probability compared with productive loan.

\section{Conclusions and recommendations}

According to the sample data provided by a branch of Hubei Rural Commercial Bank, this paper used Probit model to analyze the influence factors of the credit risk of farmer loan, and the empirical findings are:

(1) Total household assets and the number of family labor have significant negative correlation relationship with the credit risk of farmer loan, while total household debt and loan rate have positive correlation with it. 
(2) The farm households who have children in university and secured loans take greater credit risk;Consumption loan have greater credit risk than productive loan.

(3) The factors of householder age and educational level, annual household income, loan term and loan amount do not have a significant impact on the credit risk of farmer loan.

The conclusions of this paper have certain reference significance to the research of the credit risk evaluation of farmer loan of Rural Commercial Bank and its management. When Rural Commercial Bank provides the loans to farmers should focus on the following two questions:

First, do a good job on "Three loan check system." Do key investigation on family labor and whether to have children in university before providing loans. For the family with children in university may consider offering preferential interest rates, reimbursement deadline, etc. During the period of the loan, focusing on the household assets and debit, and verify the authenticity of the guarantee object. Tracking the actual use of the loan at the same time, for consumption loan, the bank can consider limiting loan amount, term, etc. Post-loan management, early discovery and compensate for the potential risk which has not yet appeared and improve the quality of loans. Second, take preferential interest rate policy. With the open of loan interest rate control of Rural Commercial Bank in our country, the rural commercial bank in addition to obtain the appropriate profit, can consider to give special household loans with preferential interest rates or lower lending rates. This can ease the pressure of the loan interest, support the "three rural" work, and encourage farmers to payment timely.

\section{Acknowledgement}

This research was financially supported by Center for Industrial Policy and Management Research: Research on Credit Risk Management of Hubei Province Farm Loan (CY20150201); The Hubei province department of education Humanities and Social Science Research Project: Financial Crisis Shock, Financing Constraints and Corporate Value: Theoretical Exploration and Empirical Research (14D004); Social science fund of Hubei province: Financial Development and Current Account Sustainability: Theoretical Exploration and Empirical Research (2013129).

\section{References}

[1] M. Godquin. Microfinance repayment performance in Bangladesh: How to improve the allocation of loans by MFIs [J]. World Development, 2004, 32(11): 1909-1926.

[2] Yan L, Qinggao L, Cuixia Z. Development Law of Farmers' Loan Behavior and Its Influence Factors_-Based on 6 Years Longitudinal Data of 573 Peasant Households in Shandong Province [J]. Nankai Economic Studies, 2014, (5):29-34.

[3] Edward I. Aitman. Financial rations discriminate analysis and the prediction of corporate bankruptcy [J]. Journal of Finance, 1968, 23(9): 589-609.

[4] Li-yan L. Study on the Credit Risk Influencing Factors of the Loans to Farmers of Rural Credit Cooperatives Based on the Survey of Heilongjiang Province [J]. Journal of Anhui Agricultural Sciences, 2013, 41(13):6023-6025.

[5] Xia N, Kun W, Wenjing M. Research on the Effect of Credit Cognition upon Farmer's Borrowing \& Lending and Repaying Behavior__ An Empirical Analysis on Henan Province [J]. Credit Reference, 2014, (7):21-26. 